\title{
PROFITABILITY AND ECONOMIC EFFICIENCY OF GROUNDNUT PRODUCTION IN BENUE STATE, NIGERIA
}

Ani $\mathrm{DP}^{1^{*}}, \mathrm{Umeh} \mathrm{JC}^{1}$ and EA Weye ${ }^{1}$

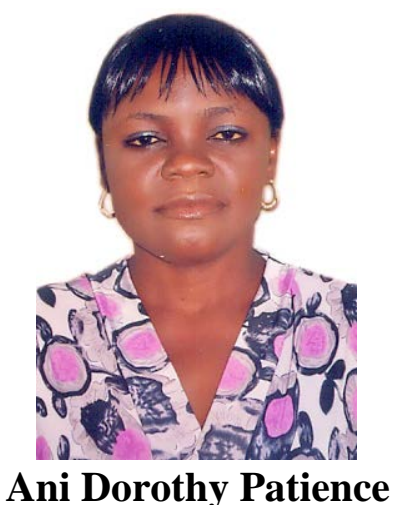

*Corresponding author’s email: doranonye@yahoo.com

${ }^{1}$ Department of Agricultural Economics, Federal University of Agriculture Makurdi, Benue State Nigeria. 


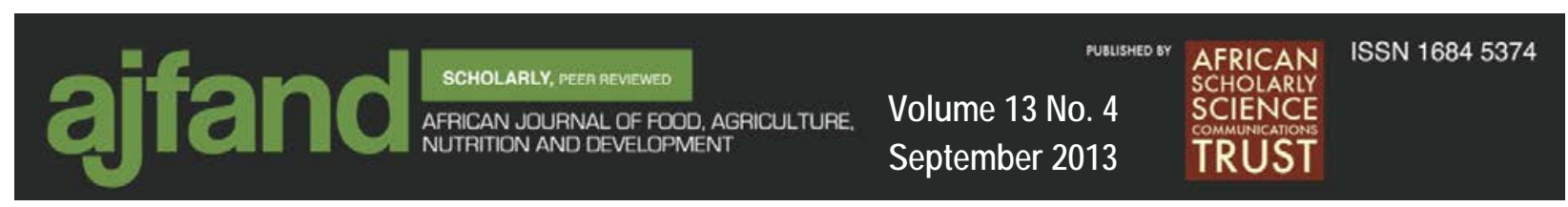

\section{ABSTRACT}

There has been a remarkable reduction in the contribution of groundnut to Nigeria's foreign exchange earnings since the discovery of petroleum resources. There is need to re-position this valuable crop to assume its rightfull position in the nation's economy. Thus, this study assessed the profitability of groundnut production and level of technical and allocative efficiencies of the farmers using Benue State as a case study. Multi-stage sampling technique, which involves purposive selection of two Local Government Areas (Makurdi and Ogbadigbo) and subsequent random selection of groundnut farmers from the selected three communities was adopted in collecting cross-sectional data from 270 groundnut farmers using structured questionnaire and oral interview. Descriptive statistics, gross margin analysis and Stochastic Frontier Model were used to analyse the data. The study found that the mean gross margin per hectare of groundnut was $\$ 1,897.86$ per month while the profitability test shows that it is profitable $(\mathrm{t}=6.87 ; \mathrm{P} \leq 0.01)$. However, the key variables that influence profitability are hired labour, cost of seed, agrochemical and cost of fertilizer. Meanwhile, the mean technical efficiency estimate of groundnut farmers in the study area was found to be as low as $4 \%$. This could be attributed to high demand for labour, land and agrochemicals which are the critical factors that play a significant role in groundnut production. The socio-economic factors that affect groundnut production in the study area include farmers' age, household size and annual income. Similarly, an average farmer spent about $28 \%$ above the minimum frontier cost. Furthermore, the elasticity of cost of production with respect to cost of hired labour and cost of seed was found to be relatively high indicating their importance in groundnut production. More land should be put into groundnut production and farmers should be given essential agricultural inputs that will enhance the productivity of this cash crop. The study further recommends the development and dissemination of simple machines that can facilitate the stages involved in the production of groundnut.

Key words: Groundnut, Profitability, Frontier, Efficiency, Allocative 


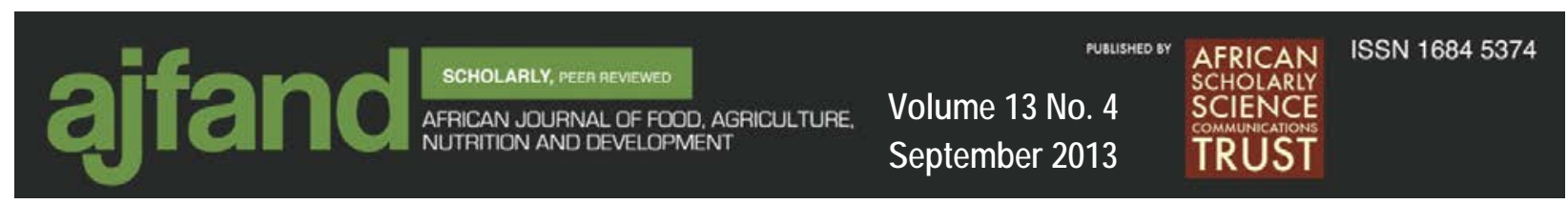

\section{INTRODUCTION}

Groundnut (Arachis hypogea), an annual plant herb (legume) comes from the pea family of Fabaceae. It is also known as peanut, earthnut, monkeynut and goobers in U.S. and British terms [1]. Groundnut seeds contain $40-50 \%$ fat, $20-50 \%$ protein and $10-20 \%$ carbohydrate [2]. Thus, nutritionally, it is a good source of vitamins and essential minerals. Groundnut seeds are consumed directly as raw, roasted or boiled (meal) and the oil extracted from the seeds is used as culinary oil. The oil is used in making margarine, crackers/cookies, candy, salted groundnut, salad oils nut chocolates, sandwiches and soaps. Furthermore, groundnut plants are used as animal feed (oil pressings from seeds, green material and straw) and industrial raw material (oil cakes and fertilizer). These multiple uses of the groundnut plant makes it a good cash crop for domestic markets as well as for foreign trade in several developing and developed countries.

Groundnut is one of the most popular and universal crops cultivated in more than 100 countries in six continents [3]. It is grown in 25.2 million hectares of land with a total production of 35.9 million metric tons [4]. It is the 13th most important crop and the 4th most important oilseed crop of the world [1]. Major groundnut producing countries are China (40.1\%), India (16.4\%), Nigeria (8.2\%), USA (5.9\%) and Indoesia (4.1\%) [5]. Before the second world war, Nigeria's groundnut figured prominently in world trade accounting for $29 \%$ of Africa's export and $12 \%$ of the world's export. Between 1950s and 1970s before the discovery of oil, Nigeria contributed $50 \%$ and $30 \%$ of the African and world exports, respectively. The decline in groundnut production in Nigeria has been attributed to the discovery of crude oil, groundnut rosette epidemic, drought and lack of organised inputs procurement and marketing [6].

According to Adama [7], over 330 products can be commercially produced from groundnut and jobs can be directly created from enhanced groundnut production with small improvement in the technology and the use of improved variety with corresponding increase of cultivated acreage. As a legume crop, groundnut adds nitrogen to the soil by increasing soil fertility. In recent times, there has been increased awareness in the cultivation of food legumes like groundnut, not only as food but as soil fertilizer. This reduces the farmers' demand for inorganic fertilizer.

Despite numerous efforts by the Nigerian Government to rivatilize the production of this crop through research, crop improvement practices and vast resources of land, there seems to be inadequate supply of groundnuts to meet both the local and international market demand. Consequently, with the huge potential of this cash crop, there is need to investigate the level of productivity and efficiency of its production in Nigeria. No systematic study has investigated the profitability, technical and allocative efficiency of groundnut in Benue State. Thus, the two major objectives of this study were to assess the profitability of the groundnut crop in Benue State and to determine the level of technical and allocative efficiencies of production of the crop in the study area. 


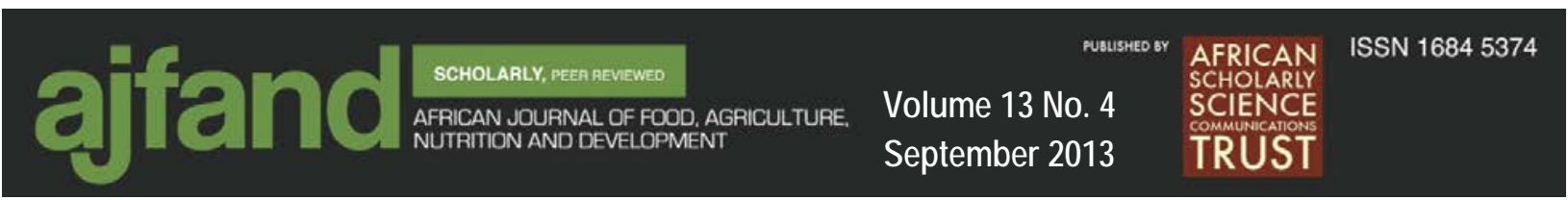

\section{METHODOLOGY}

The study was carried out in Benue State, in the middle belt zone of Nigeria, located between latitude $8^{0}-10^{0} \mathrm{~N}$ and between longitudes $6^{0}-8^{0} \mathrm{E}$. It has a total landmass of about 33,955 $\mathrm{km}^{2}$ with 23 Local Government Areas. The State is politically and agriculturally divided into three zones: A,B, and C with a population of 4,219,244 people, and 413,159 farm families [8, 9]. Benue State shares boundary with Nasarawa State to the North, Taraba State to the East, Cross-River to the South, Kogi State at the West and Cameroon Republic to the South-East.

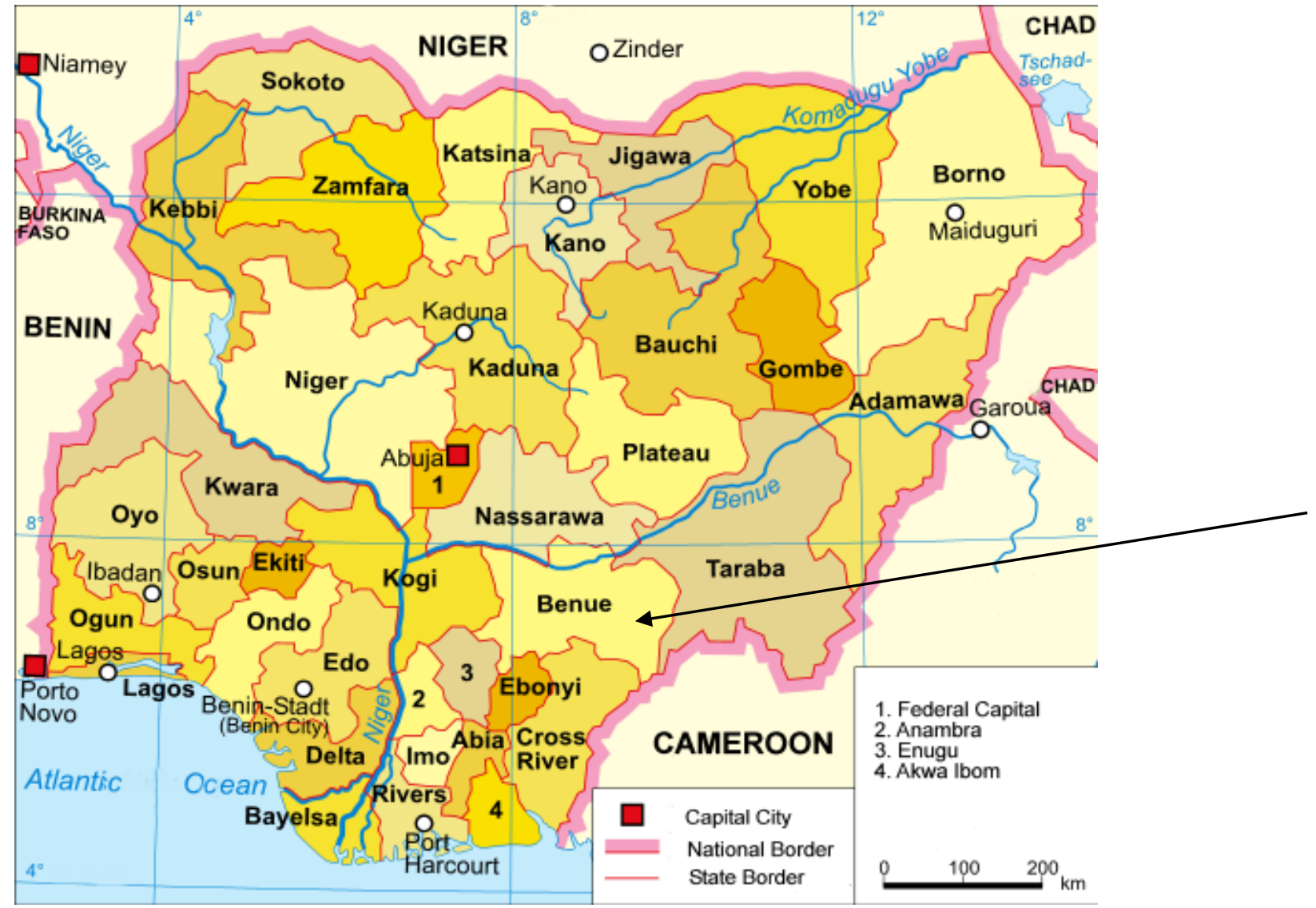

Figure 1: Map of Nigeria showing the study area (Benue State)

A multi-stage sampling technique was adopted in selecting the respondents. First, a purposive selection of two Local Government Areas (LGAs) (Makurdi and Ogbadigbo) was made following the choice of these LGAs as sites for 'legume technology' by First Bank of Nigeria (Plc) Professorial chair in Agronomy. From the two LGAs selected, Odoba, Pila and Shaminja communities were purposively selected based on the presence of demonstration sites in the communities. Subsequently, simple random sampling technique was used in the selection of farmers at the community level. With the sampling frame drawn, a sampling proportion of $39.2 \%$ of farmers in each community was taken which gave a total of 270 respondents. 


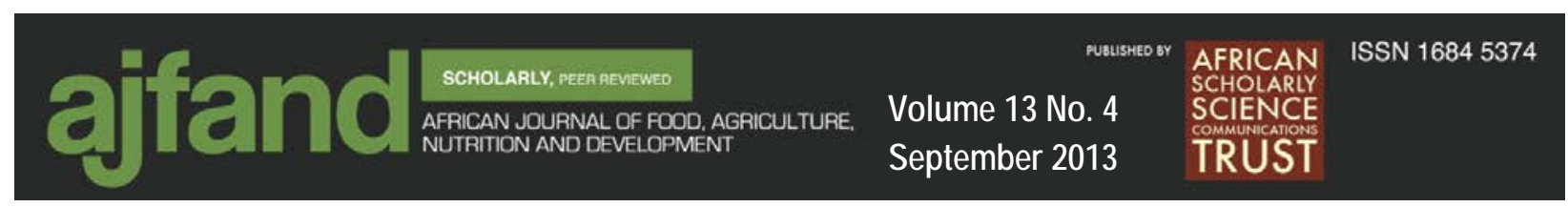

Data for this study were collected by the use of a well-structured questionnaire administered to the 270 selected groundnut farmers in the study area. Both descriptive and inferential statistics were used to analyze the data for the study. Gross margin and Stochastic Frontier production function were used in estimating the profitability; and technical and allocative efficiencies of the farmers, respectively. The parameters of the stochastic frontier model were obtained by the maximum likelihood estimation method using the computer programme, FRONTIER version 4.1 [10].

\section{Model Specification}

\section{Technical efficiency}

Technical efficiency model is embedded in equations linking groundnut outputs to resources inputs on one hand and groundnut output to inefficiency model on the other hand. Inefficiency effects is linked to the age of farmers, educational level, farming experience, annual income, household size, extension contact and variety of crop planted. Cobb-Douglas Stochastic Frontier production function was assumed to be the appropriate model for the analysis of the farm data. The estimated Cobb-Douglas model was expressed as:

$$
\begin{gathered}
\operatorname{Ln} Y_{i}=\beta_{0}+\beta_{1} \operatorname{Ln} X_{1 i}+\beta_{2} \operatorname{Ln} X_{2 i}+\beta_{3} \operatorname{Ln} X_{3 i}+\beta_{4} \operatorname{Ln} X_{4 i}+\beta_{5} \operatorname{Ln} X_{5 i}+V_{i} \\
-U_{i} \ldots \ldots \ldots \ldots(1)
\end{gathered}
$$

Where

Ln -denotes natural logarithm to base e.

$Y_{i}$ - represents output of the ith farmer (in $\mathrm{kg}$ ).

$\beta_{i}$ - represents the unknown parameters associated with the explanatory variables in the production function $(1=0,1,2)$

$X_{1 i}=$ farm size - total amount of land under groundnut cultivation (ha).

$X_{2 i}=$ quantity of seed (kg/ha).

$X_{3 i}=$ quantity of inorganic fertilizer (in $\mathrm{kg} / \mathrm{ha}$ ).

$X_{4 i}=$ quantity of agro-chemicals (litres/ha).

$X_{5 i}=$ amount of hired labour in mandays.

$V_{i}$ - random errors that are assumed to be independently and identically distributed of the $\mathrm{U}_{\mathrm{i}}$.

$U_{i}{ }^{-}$non-negative random variables associated with technical inefficiency of production which are assumed to be independently distributed, such that $U_{i}$ is obtained by truncation (at zero ) of the normal distribution with variance $\sigma^{2}$ and mean $\mathrm{U}_{\mathrm{i}}$ where the mean is defined by: 


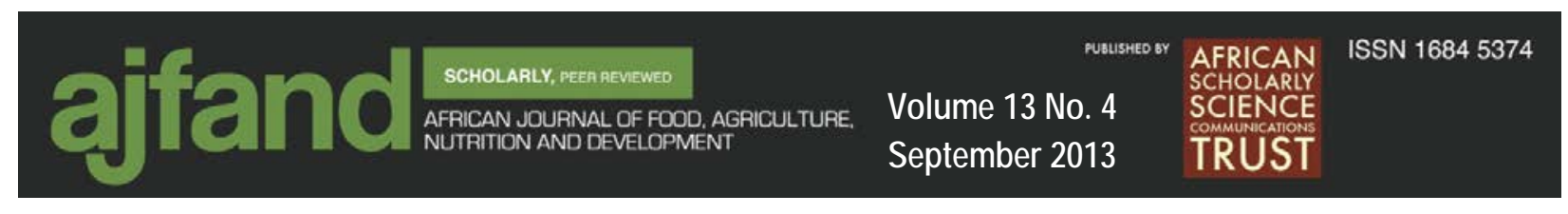

$$
U_{i}=\sigma_{0}+\sigma_{1} Z_{1 i}+\sigma_{2} Z_{2 i}+\sigma_{3} Z_{3 i}+\sigma_{4} Z_{4 i}+\sigma_{5} Z_{5 i}+\sigma_{6} Z_{6 i}+\sigma_{7} Z_{7 i} \ldots \text { (2) }
$$

Where

$\sigma$ is a $(7 \times 1)$ vector of unknown parameters to be estimated.

$\mathrm{Z}_{1}$ is age of farmers.

$\mathrm{Z}_{2}$ is years of formal education.

$\mathrm{Z}_{3}$ is farming experience.

$\mathrm{Z}_{4}$ is annual farm income of farmers in Nigeria Naira (

$\mathrm{Z}_{5}$ is extension contact.

$Z_{6}$ is household size (Headcount / number of persons in a household).

$\mathrm{Z}_{7}$ is variety of groundnut (Improved variety $=1$, local variety $=0$ ).

\section{Allocative (cost) Efficiency}

The allocative (cost) efficiency function is derived analytically and defined as follows:

$\operatorname{Ln} C_{1}=\beta_{0}\left(Y^{*}\right)+\beta_{1}\left(P_{1 i}\right)+\beta_{2} \operatorname{Ln}\left(P_{2 i}\right)+\beta_{3} \operatorname{Ln}\left(P_{3 i}\right)+\beta_{4} \operatorname{Ln}\left(P_{4 i}\right)+\beta_{5} \operatorname{Ln}\left(P_{5 i}\right) \ldots$ (3)

where

$\mathrm{C}_{1}=$ the cost of production of groundnut in Naira ( $)$.

$Y^{*}=$ the total output measured in Naira.

$i=$ refers to individual production farm.

$P_{1 i}=$ total output in $\mathrm{kg} / \mathrm{ha}$.

$P_{2 i}=$ cost of seed ( $\left.\mathbb{A} / \mathrm{ha}\right)$.

$P_{3 i}=$ cost of inorganic fertilizer ( $\$ /$ ha).

$P_{4 i}=$ cost of agrochemical ( $\$ /$ ha).

$P_{5 i}=$ cost of labour ( $\# /$ ha).

Cost/Allocative inefficiency frontier model is given as:

$U_{i}=\sigma_{0}+\sigma_{1} Z_{1 i}+\sigma_{2} Z_{2 i}+\sigma_{3} Z_{3 i}+\sigma_{4} Z_{4 i}+\sigma_{5} Z_{5 i}+\sigma_{6} Z_{6 i}+\sigma_{7} Z_{7 i}$ where

where $Z_{1}$ to $Z_{7}$ are the same as stated above.

\section{RESULTS}

The result of gross margin analysis of groundnut production in the study area is presented in table 1 . The result indicates that an average farmer spends about $49.50 \%$ of the total variable costs on hired labour. Similarly, about $31.40 \%$ of the mean total variable cost is used in procuring seed. However, the costs of inorganic fertilizer and agrochemical represent as low as $11.46 \%$ and $7.64 \%$ of the total variable costs, respectively. The total variable cost per hectare was one-third the total revenue per hectare. The gross margin per hectare as 22,774.37. Moreover, the result of profitability test (table 1 ) shows that the total revenue is significantly higher ( $t=6.87$; $\mathrm{P} \leq 0.01)$ than the total variable cost, indicating that their difference is not by chance.

The result of Cobb-Douglas stochastic estimation is presented in table 2. The statistical significance of sigma squared indicates the appropriateness of the 
model.The gamma value of 0.99 means that about $99 \%$ of the variations in groundnut output is attributed to variations in technical efficiencies of farmers. The result shows that the elasticity of production with respect to farm size, quantity of agrochemicals and labour are $0.29,0.094$ and 0.25 , respectively, and are, therefore, the major determinants in groundnut production in the study area.

The analysis of technical efficiency in groundnut production presented in table 3 revealed a technical efficiency range of 0.004 to 0.83 with a mean of 0.0387 . The result also shows that majority of the farmers (98.5\%) have technical efficiency that ranged from 0.004 to $0.199 ; 0.4 \%$ have technical efficiency estimates of 0.2 to 0.399 . More so, the result of inefficiency model (table 2) reveals that age

$(-0.822)$, annual income $(-0.32)$, and household size (0.48) are the major determinants of technical efficiency in groundnut production in the study area.

Furthermore, the result of stochastic cost frontier model estimates in groundnut production presented in table 4 , shows that output $(-0.019)$, labour cost $(0.59)$, cost of seed (0.41), cost of inorganic fertilizer (0.011) and cost of agrochemicals (0.0148) have significant influence on the cost of groundnut production. Moreover, the elasticity of cost of production in terms of hired labour and seed was found to be relatively high, indicating their relative importance in groundnut production. The elasticity of cost of production in terms of quantity of inorganic fertilizer and agrochemical were found to be low.

The result in table 5 shows that the allocative efficiencies among farmers differed substantially, ranging from 1.0001 to 3.233 with a mean of 1.275 . The result further shows that majority (82.6\%) of the farmers have allocative efficiency estimates between 1.00 and 1.499 , while only $0.7 \%$ have between 3.0 and 3.50 . The result of inefficiency model presented in the lower section of table 4 shows that age (0.096), education (0.49), annual income (0.396), variety (0.146), extension contact $(-0.17)$ and, household size (-2.35) are the major determinants of allocative efficiency in groundnut production.

\section{DISCUSSION}

\section{Profitability Analysis of groundnut production}

Among the variable costs involved in the production of groundnut, the cost of labour rated highest. It accounted for nearly half of the total variable costs. This shows that the crop is labour-intensive. Similarly, another important variable in groundnut production in the study area is the cost of seed. About two-thirds (31.40\%) of the total variable cost is used for procuring seeds. However, the costs of inorganic fertilizer and agrochemical were minimal (11.46\% \& 7.64\% of total variable cost, respectively) suggesting the low use of the variables in the study area. The total variable cost per hectare was found to be one-third the total revenue per hectare. The gross margin per hectare was $\$ 1,897.86$ per month.

\section{Stochastic Frontier Production Function for groundnut}

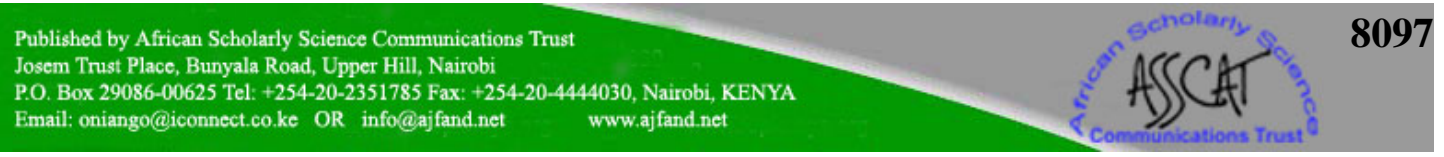


The result of Cobb-Douglas stochastic production frontier model of groundnut shows that the perfomance of the model in terms of sigma squared and gamma are large and significantly different from zero at $1 \%$. This indicates goodness of fit and correctness of the distributional assumptions of the error term. This implies that the conventional production function is not an adequate representation of the data. The value of gamma of 0.99 means that about $99 \%$ of the variations in groundnut output is attributed to variations in technical efficiencies of farmers.

The result shows that farm size, quantity of agrochemicals and labour significantly influenced groundnut output in the study area as observed by Amaza, Onu \& Okunmadewa [11]. The output elasticity of farm size, agrochemical and labour were all less than unity. The sum of the coefficients (output elasticity) of the variables of the Cobb-Douglas stochastic frontier production model is 0.6586. This indicates decreasing return to scale, suggesting that a proportionate increase in all inputs used in groundnut production would lead to a more than proportionate decrease in groundnut production in Benue State. Analysis of technical efficiency in groundnut production revealed that an average groundnut farmer operates at a low level. This implies that technical efficiency of farmers could be increased by less use of inputs in groundnut production.

Furthermore, age, annual income, and household size are the major determinants of groundnut production in the study area. This result suggests that technical inefficiency effects in groundnut production in Benue State declined with increase in age and annual farm income while it increases with household size. In other words, old farmers with high annual income with relatively less household size achieved higher levels of technical efficiency in groundnut production in Benue State.

\section{Stochastic Frontier Cost Function for Groundnut}

The result of stochastic cost frontier model estimates in groundnut production reveals that the performance of the model in terms of $\lambda$ and $\delta$ are large and signifcant at $1 \%$. The magnitude of gamma $(\gamma)$ found at 0.99 implies that $99 \%$ of the variations in the cost of production of groundnut in Benue State are accounted for by differences in allocative efficiency of farmers. Output, labour cost, cost of seed, cost of inorganic fertilizer and cost of agrochemicals have significant influence on the cost of production of groundnut in the study area. This implies that these variables are the major determinants in allocative efficiency of groundnut production in the study area. Moreover, the elasticity of cost of production with respect to cost of hired labour and cost of seed was found to be relatively high, indicating their relative importance in groundnut production. The elasticity of cost of production in terms of quantity of inorganic fertilizer and agrochemical were found to be low. This may be attributed to the low use of these inputs by farmers.

The mean allocative efficiency among groundnut farmers was 1.275. This implies that an average groundnut farmer spends about $28 \%$ above the minimum cost of production. This also implies that allocative efficiency could be increased by $28 \%$ through cost allocation of resources, given the current state of technology. The result 


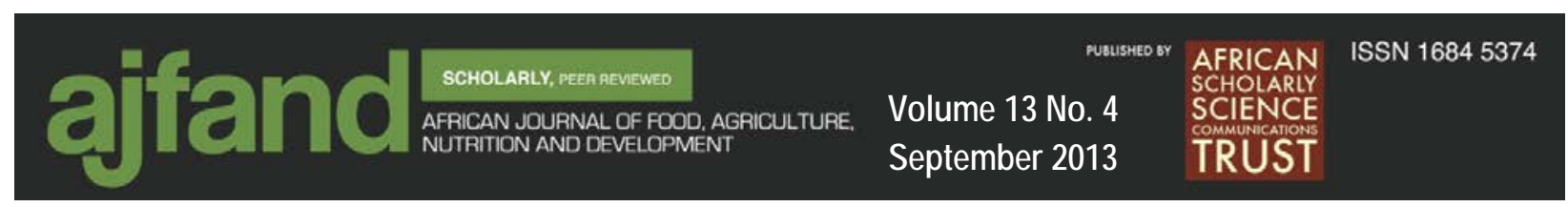

of inefficiency model revealed also that age, education, annual income, variety, extension contact and household size are the major determinants of allocative efficiency in groundnut production. This implies that increase in age, education and annual income and the use of improved variety of groundnut decreases the allocative efficiency of farmers. However, increase in household size and extension contact increases the allocative efficiency of groundnut production in the study area.

\section{CONCLUSION AND RECOMMENDATIONS}

The study assessed the profitability and economic efficiencies of groundnut production in Benue state. Groundnut production was found to be moderately profitable with a gross margin of $\$ 22,774.37$. Groundnut farmers in the study area were found to be technically inefficient since the average farmer operated at $4 \%$. Also, an average groundnut farmer spent about $28 \%$ above the minimum cost of production. Age, annual income and household size are the major determinants of technical and allocative efficiencies of groundnut farmers in the study area.

It was recommended that farm mechanization be promoted and encouraged among groundnut farmers by developing and disseminating simple machines to forestall labour shortage. This will not only ensure greater productivity and efficiency but will attract youth into the agricultural sector. More farm lands should be put into groundnut production in the study area. Again, policies designed to enhance the use of less production inputs by the groundnut farmers in Benue State would lead to increase in groundnut output and increased profitability of the crop in the State. 
Table 1: Descriptive Statistics of Cost and Returns in Groundnut Production in the Study Area

\begin{tabular}{|c|c|c|c|c|c|c|c|c|c|}
\hline Crop & Statistics & $\begin{array}{l}\text { Revenue } \\
(\mathrm{A} / \mathrm{Ha})\end{array}$ & $\begin{array}{l}\text { Total Variable } \\
\text { Cost(A/Ha) }\end{array}$ & $\begin{array}{l}\text { Cost of } \\
\text { Seed } \\
(\mathrm{A} / \mathrm{Ha})\end{array}$ & $\begin{array}{l}\text { Cost of } \\
\text { Labour } \\
(\mathrm{A} / \mathrm{Ha})\end{array}$ & $\begin{array}{l}\text { Cost of } \\
\text { Ferilizer } \\
(\mathrm{A} / \mathrm{Ha})\end{array}$ & $\begin{array}{l}\text { Cost of } \\
\text { Agrochemical( } \\
\mathrm{N} / \mathrm{Ha})\end{array}$ & $\begin{array}{l}\text { Gross } \\
\text { Margin } \\
(\mathrm{A} / \mathrm{Ha})\end{array}$ & $\begin{array}{l}\text { Profitability } \\
\text { test }\end{array}$ \\
\hline & $\mathrm{N}$ & 270 & 270 & 270 & 270 & 270 & 270 & 270 & \\
\hline GROUND & Mean & 36037.3 & 13262.96 & 4164.94 & 6564.87 & 1520.01 & 1013.14 & 22774.37 & \\
\hline \multirow[t]{5}{*}{ NUT } & Mode & 25000 & 20000 & 3000 & 5000 & 0 & 0 & 15000 & \\
\hline & Std. Deviation & 52638.8 & 14035.10 & 2897.58 & 11391.12 & 2709.52 & 2068.20 & 52822.44 & \\
\hline & Minimum & 3250 & 1000 & 417 & 500 & 0 & 0 & -112600 & \\
\hline & Maximum & 800000 & 176600 & 16000 & 150000 & 21000 & 10875 & 783500 & \\
\hline & t-value & & & & & & & & 6.869 ** \\
\hline
\end{tabular}

Source: Analysis of field data, 2009 
Table 2: Cobb-Douglas Stochastic Frontier Estimates for Groundnut Production in Benue State

\begin{tabular}{llll}
\hline Variables & Parameter & Coefficient & t-ratio \\
\hline Stochastic production frontier & & \\
Constant & $\beta_{0}$ & $8.28^{* *}$ & 9.43 \\
Ln Farm size & $\beta_{1}$ & $0.29^{* *}$ & 3.608 \\
Ln Seed rate & $\beta_{2}$ & 0.017 & 0.24 \\
Ln Quantity of & $\beta_{3}$ & -0.0024 & -0.22 \\
fertilizer & & & \\
Ln Quantity of & & & \\
Agro-chemical & $\beta_{4}$ & $0.094^{* *}$ & 4.74 \\
Ln Hired labour & $\beta_{5}$ & $0.25^{* *}$ & 3.92 \\
Inefficiency model & & & \\
Constant & $\delta_{0}$ & $9.93^{* *}$ & 7.72 \\
Age & $\delta_{1}$ & $-0.822^{* *}$ & -4.115 \\
Educational level & $\delta_{2}$ & -0.039 & -0.40 \\
Farming Experience & $\delta_{3}$ & 1.14 & 1.94 \\
Annual income & $\delta_{4}$ & $-0.32^{* *}$ & -5.20 \\
Extension contact & $\delta_{5}$ & 0.04 & 0.717 \\
Household size & $\delta_{6}$ & $0.48^{* *}$ & 3.610 \\
Variety & $\delta_{7}$ & 0.165 & 1.65 \\
Variance & & & \\
Parameter & & -218.95 & 11.46 \\
Sigma Square & $\delta^{2}$ & & \\
Gamma & $\Gamma$ & $0.297^{* *}$ & \\
Log likelihood & & $0.99^{* *}$ & \\
function & & & \\
\hline
\end{tabular}

**significant at $1 \%$ level;*significant at $5 \%$ level

Source: Analysis of Field data, 2009 
Table 3: Distribution of Respondents by Technical Efficiency Estimates of Groundnut Enterprise

\begin{tabular}{lll}
\hline EFFICIENCY RANGE & FREQUENCY & PERCENTAGE \\
\hline $0.0040<0.2$ & 266 & 98.5 \\
$0.2<0.4$ & 1 & 0.4 \\
$0.4<0.6$ & 1 & 0.4 \\
$0.6<0.8$ & 1 & 0.4 \\
$0.8<1.00$ & 1 & 0.4 \\
Total & 270 & 100 \\
\hline
\end{tabular}

Mean efficiency $=0.0387$

Minimum efficiency $=0.0040$

Maximum efficiency $=0.83$

Source : Analysis of Field data, 2009 
Table 4: Stochastic Cost Frontier Estimates for Groundnut Farmers in Benue State

\begin{tabular}{|c|c|c|c|}
\hline Variables & Parameter & Coefficient & T-ratio \\
\hline \multicolumn{4}{|c|}{ Stochastic Cost frontier } \\
\hline Constant & $\beta_{0}$ & $0.87 * *$ & 29.53 \\
\hline Ln Output & $\beta_{1}$ & $-0.019 * *$ & -14.69 \\
\hline Ln Labour cost & $\beta_{2}$ & $0.59 * *$ & 105.29 \\
\hline Ln Cost of seed & $\beta_{3}$ & $0.41^{* *}$ & 66.76 \\
\hline Ln Cost of fertilizer & $\beta_{4}$ & $0.011^{* *}$ & 29.46 \\
\hline $\begin{array}{l}\text { Ln Cost of } \\
\text { agrochemical }\end{array}$ & $\beta_{5}$ & $0.0148^{* *}$ & 65.53 \\
\hline \multicolumn{4}{|l|}{ Inefficiency model } \\
\hline Constant & $\delta_{0}$ & $-9.49 * *$ & -16.63 \\
\hline Age & $\delta_{1}$ & $0.96 * *$ & 12.92 \\
\hline Educational level & $\delta_{2}$ & $0.49 * *$ & 6.21 \\
\hline Farming Experience & $\delta_{3}$ & 0.061 & 1.22 \\
\hline Annual income & $\delta_{4}$ & $0.396 * *$ & 12.75 \\
\hline Extension contact & $\delta_{5}$ & $-0.17^{* *}$ & -4.20 \\
\hline Household size & $\delta_{6}$ & $-2.35^{* *}$ & -13.06 \\
\hline Variety & $\delta_{7}$ & $0.146^{*}$ & 1.98 \\
\hline \multicolumn{4}{|l|}{ Variance } \\
\hline \multicolumn{4}{|l|}{ Parameter } \\
\hline Sigma Square & $\delta^{2}$ & $0.29 * *$ & 9.73 \\
\hline Gamma & $\Gamma$ & $0.99 * *$ & 51998896 \\
\hline $\begin{array}{ll}\text { Log } & \text { likelihood } \\
\text { function } & \end{array}$ & & 181.902 & \\
\hline LR test & & 181.89 & \\
\hline
\end{tabular}

**significant at $1 \%$ level, ${ }^{*}$ significant at $5 \%$ level

Source: Analysis of field data, 2009 
Table 5: Distribution of Respondents by Allocative Efficiency Estimates of Groundnut Enterprise

\begin{tabular}{lll}
\hline EFFICIENCY RANGE & FREQUENCY & PERCENTAGE \\
\hline $1.00<1.50$ & 223 & 82.6 \\
$1.50<2.00$ & 31 & 11.5 \\
$2.00<2.50$ & 7 & 2.6 \\
$2.50<3.00$ & 7 & 2.6 \\
$3.00<3.50$ & 2 & 0.7 \\
Total & 270 & 100.0 \\
\hline
\end{tabular}

Mean efficiency $=1.275$

Minimum efficiency $=1.0001$

Maximum efficiency $=3.2326$

Source : Analysis of Field data, 2009 


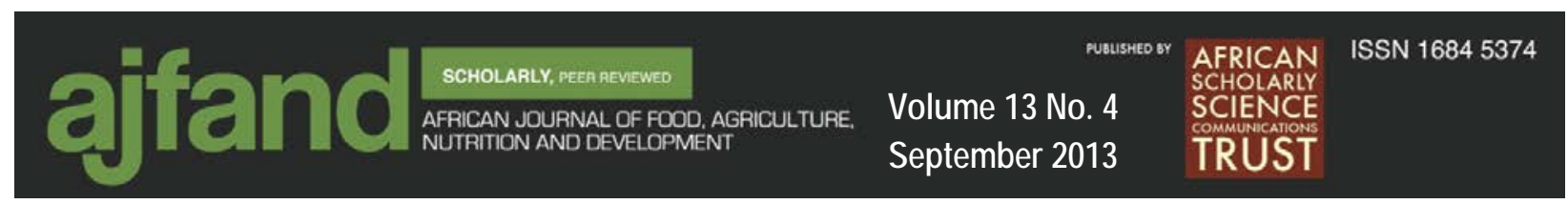

\section{REFERENCES}

1. Vijaya Kumar $\mathbf{P}$ Agrometeorology and groundnut production Chapter 13 B 2007.

2. Vijaya Kumar P, Ramakrishna YS, Krishna-Murty K, Ashok-Kumar B and AM Shekh Identifying the climatic constraints for optimum production of groundnut and delineating the areas with highest production potential on climatic basis. In: Proc. of the symposium on Tropical crop Research and Development India International, Trissur, India 1997.

3. Nwokolo E Peanut (Arachis hypogea L.) In: Food and Fee from legumes and oilseeds E Nwokolo and J Smartt Eds. pp 49-63. New York: Chapman and hall, ODA (Overall Development Administration) 1984. Annual report No. 13 Response of Groundnut to the distribution of rainfall or irrigation. Nottingham, U.K: University of Nottingham 1996.

4. FAO (Food and Agriculture Organization) production Yearbook, Vol.60, Rome Italy 2006.

5. Shuren G Present Situation and Prospects for Groundnut Production in China. In Achieving High Groundnut Yields. Pp. 17-26. Patancheru, India: ICRISAT1995.

6. Misari SM, Boye-Goni S and BK Kaigama Groundnut improvement, production, management, utilization in Nigeria: Problems and prospects. First ICRISAT Regional Groundnut Meeting for West Africa, Niamey Niger 1988; 61-64 ICRISAT.

7. Idama A Perspectives on Industrialization of Adamawa State. Paraclete Publishers, Yola, 2000; 15-33.

8. BNARDA Benue Agricultural and Rural Development Authority Crop production Manual for Benue State, 1997; 7-14.

9. National Population Commission (NPC) National Population Census, Federal Republic of Nigeria official gazette, 94 (4) Lagos Nigeria 2006.

10. Coelli TJ A guide to Frontier version 4.1. A Computer Programme for Stochastic Frontier Production and Cost Function Estimation. Department of Econometric, University of New England, Armidale.NSW2351 Australi 1994.

11. Amaza PS, Onu JI and FY Okunmadewa Identification of factors that influence the technical efficiency of cotton farmers in Nigeria. Nigeria Agric. Dev.stud., 2000; 2:133-45. 